\title{
Chemical Characteristics of Biomass Ashes
}

\author{
Grzegorz Zając ${ }^{1}\left(\mathbb{D}\right.$, Joanna Szyszlak-Bargłowicz ${ }^{1, *}{ }^{\mathbb{D}}$, Wojciech Gołębiowski ${ }^{1}$ (1) \\ and Małgorzata Szczepanik ${ }^{2}$ \\ 1 Department of Power Engineering and Transportation, Faculty of Production Engineering, \\ University of Life Sciences in Lublin, Gleboka 28, 20-612 Lublin, Poland; \\ grzegorz.zajac@up.lublin.pl (G.Z.); wojciech.golebiowski@up.lublin.pl (W.G.) \\ 2 Department of Applied Mathematics and Computer Science, Faculty of Production Engineering, \\ University of Life Sciences in Lublin, Gleboka 28, 20-612 Lublin, Poland; \\ malgorzata.szczepanik@up.lublin.pl \\ * Correspondence: joanna.szyszlak@up.lublin.pl; Tel.: +48-81-531-97-24
}

Received: 30 August 2018; Accepted: 22 October 2018; Published: 24 October 2018

check for updates

\begin{abstract}
The aim of the conducted research was to obtain information on the main components of ashes from 35 biomass species used in combustion processes to obtain reference data for the development of utility possibilities for these ashes, with particular emphasis on agricultural use. The examined biomass samples were divided into groups depending on origin: woody biomass and energetic woody plants I-WWB, herbaceous and grassy energy plants II-EC, agricultural waste III-AR, forest waste IV-FR and waste from the agri-food industry V-AFIW. The analysis of the studied elements contents was carried out in the designated groups. The chemical composition of ash was dominated by the macroelements $\mathrm{Ca}, \mathrm{K}, \mathrm{P}$ and $\mathrm{S}$, which suggests the possibility of their agricultural use. At the same time, the low content of toxic elements such as As and $\mathrm{Pb}$ should not be a limiting feature in their use, with the exception of wood biomass. In addition, ashes obtained from the biomass combustion were enriched with microelements such as $\mathrm{Zn}, \mathrm{Cu}$ and $\mathrm{Mn}$, which further increases their possibilities of fertilizer use. The potential use of ash from each type of biomass in the aspect of its chemical composition should be considered individually, regardless of the division into groups depending on the origin of biomass.
\end{abstract}

Keywords: biomass ashes; chemical composition; biomass ash utilization

\section{Introduction}

Renewable energy sources play a key role in current global strategies to reduce greenhouse gas emissions and, partly, in efforts to replace fossil fuels [1,2]. Biomass is one of the most important sources of renewable energy. The construction of intelligent energy systems based on biomass as a source of primary energy enables strengthening economic, environmental, and social benefits [3].

The use of biomass potential for heating purposes in the municipal and housing sector should include not only compacted biomass fuel, but also biomass fuels with low heating value and bulk density as well as waste biomass generated during the production of high calorific value food [4-9], based on effective and low emission fuel power units suitable for small scale applications (individual farms and district heating networks) [10].

Ash is one of the byproducts generated during biomass burning. Combustion waste arising from the combustion of biomass in households is collected in a nonselective manner and exported to a landfill, thus constituting an additional and unnecessary burden for the environment [11].

The contents of ash-forming elements in biomass fuels vary greatly, both from fuel to fuel and within a certain fuel-type. If the properties of ash are well recognized, it is possible to apply it to agriculture for fertilizing purposes [12]. Biomass ash consists of various proportions of silicon, 
aluminum, iron, calcium, magnesium, sodium, potassium, titanium, and manganese, with heavy metals as impurities [13]. The return of ashes from the combustion of biomass to soil is the most ecological and sustainable disposal method. In this way, a significant part of the macro- and micronutrients taken by the plants returns to the soil, closing the circulation of minerals.

Numerous literature reports indicate the content of valuable nutrients in the ash from the combustion of biomass [14-17], and their use in higher doses may have a deacidifying effect and improve the physicochemical properties of light soils $[18,19]$. At the same time, ashes from biomass are characterized by a significant diversity of their properties, depending on the type of biomass burned and its origin. They can also contain harmful substances, such as heavy metals. It should be noted that, apart from the use of ashes as a fertilizer, the elements in ash may also cause problems during combustion in the furnace. Although the ash content in biomass is much smaller than in coals, their different origin and chemical nature affect the operation of boiler equipment causing, among others, increased deposition of slag and ash in the furnace or increased rate of wear of metal boiler elements due to corrosion [20]. These problems can lead to increased operating costs and reduced efficiency and availability of the device.

In view of the above, the assessment of the content of individual mineral components in ashes generated from the combustion of biomass becomes a very important problem. These analyses are necessary before the potential use of ash in agriculture and for determining the impact of ash during combustion, estimation of its impact on the boiler, or considering its use in other forms of recycling. Therefore, the aim of the work was to analyze the chemical composition of ashes generated from the combustion of various types of biomass depending on its origin, in order to develop and provide data to determine the possibility of their further use.

\section{Materials and Methods}

The research material was biomass, which could potentially be used as a raw material in thermal conversion processes. Thirty-five types of biomass were selected; samples were collected from local agricultural producers, forestry, and agri-food processing plants, as well as the experimental plantations of energy crops at the University of Life Sciences in Lublin.

The examined biomass was divided into five groups depending on its origin: I-WWB Wood and woody biomass, II-EC Energy Crops (herbaceous and grass), III-AB Agricultural Biomass (straw and hay), IV-FR Forest Residue (bark), and V-AFIW Agri-Food Industry Wastes (husks and shells). The summary of the materials and symbols used is shown in Table 1.

The research material was prepared in accordance with EN ISO 14780:2017. The obtained material was predried and then milled in an IKA 11 analytical mill. The particle size of 0.25 to $0.5 \mathrm{~mm}$ fraction was screened for the tests.

Determination of ash content was performed by the thermogravimetric method in accordance with the requirements of EN ISO 18122. A sample of approximately $1.5 \mathrm{~g}$ was prepared for analysis. Heat treatment of the samples was carried out using the LECO TGA-702 thermogravimeter. Ceramic crucibles with biomass samples ( $2 \mathrm{~g}$ each), after being loaded into the device, were heated at a rate of $20^{\circ} \mathrm{C} \mathrm{min}^{-1}$ to $950{ }^{\circ} \mathrm{C}$, and held for $60 \mathrm{~min}$ at this temperature. After this time, all the samples were cooled in an oven to $100{ }^{\circ} \mathrm{C}$ and then placed in a desiccator and chilled before further testing. To study the content of elements from the obtained ashes, pellets with the diameters of $12 \mathrm{~mm}$ were prepared.

The XRF technique was used to study the content of elements. The research was carried out using the HDMaxine analyzer of XOS Company. It is a multi-element analyzer for the determination of trace elements based on high definition fluorescence (High Definition X-ray Fluorescence-HDXRF). The analyses were performed in triplicate for each sample. The content of such elements as (in the order of atomic numbers) $\mathrm{P}, \mathrm{S}, \mathrm{K}, \mathrm{Ca}, \mathrm{Cr}, \mathrm{Mn}, \mathrm{Fe}, \mathrm{Ni}, \mathrm{Cu}, \mathrm{Zn}$, As and $\mathrm{Pb}$ of each sample was determined. The quality of analytical results regarding their accuracy was checked using standard certified materials. 
Table 1. Materials and symbols used for the samples.

\begin{tabular}{|c|c|c|}
\hline Group of Origin & Name & Code \\
\hline \multirow{10}{*}{$\begin{array}{l}\text { I-WWB Wood and } \\
\text { woody biomass }\end{array}$} & Birch wood (Betula L.) & I-BW \\
\hline & Pine wood (Pinus L.) & $\mathrm{I}-\mathrm{PiW}$ \\
\hline & Oak wood (Quercus L.) & $\mathrm{I}-\mathrm{OW}$ \\
\hline & Hornbeam wood (Carpinus L.) & $\mathrm{I}-\mathrm{HW}$ \\
\hline & Ash wood (Fraxinus L.) & I-AW \\
\hline & Wood residue chips-Forest & I-WRF \\
\hline & Wood residue chips-Municipal & I-WRM \\
\hline & Poplar wood (Populus L.) & I-PoW \\
\hline & Willow (Salix viminalis) & $\mathrm{I}-\mathrm{W}$ \\
\hline & Acacia wood (Robinia pseudoacacia L.) & I-BLW \\
\hline \multirow{8}{*}{ II-EC Energy Crops } & Virginia mallow (Sida hermaphorodita R.) & II-VM \\
\hline & Jerusalem artichoke (Helianthus tuberosus L.) & II-JA \\
\hline & Multiflorous rose (Rosa polyantha) & II-MR \\
\hline & Miscanthus giganteus (Miscanthus sinensis gigantea) & II-MG \\
\hline & Miscanthus sacchariflorus (Miscanthus sacchariflorus) & II-MS \\
\hline & Prairie cordgrass (Spartina pectinata) & II-PC \\
\hline & Common reed (Phragmites australis) & II-CR \\
\hline & Switchgrass (Panicum virgatum) & II-S \\
\hline \multirow{6}{*}{$\begin{array}{c}\text { III-AB Agricultural } \\
\text { Biomass }\end{array}$} & Wheat straw & III-WS \\
\hline & Triticale straw & III-TrS \\
\hline & Oat straw & III-OS \\
\hline & Barley Straw & III-TaS \\
\hline & Buckwheat straw & III-BS \\
\hline & Hay & III-H \\
\hline \multirow{5}{*}{ IV-FR Forest Residue } & Beech bark & IV-BB \\
\hline & Oak bark & IV-OB \\
\hline & Hornbeam bark & IV-HB \\
\hline & Ash bark & IV-AB \\
\hline & Acacia bark & IV-BLB \\
\hline \multirow{6}{*}{$\begin{array}{l}\text { V-AFIW Agri-Food } \\
\text { Industry Wastes }\end{array}$} & Cherry pits & $\mathrm{V}-\mathrm{CP}$ \\
\hline & Sunflower husk & $\mathrm{V}-\mathrm{SH}$ \\
\hline & Rape pods & V-RP \\
\hline & Apple pomace & $\mathrm{V}-\mathrm{AP}$ \\
\hline & Hazelnut shell & V-HS \\
\hline & Walnut shell & V-WS \\
\hline
\end{tabular}

The ash composition is usually classified according to the main constituents present in the mineral composition. On the basis of their concentrations, ash components were divided into three categories: macroelements: $\mathrm{P}, \mathrm{K}, \mathrm{Ca}$ and S, microelements: $\mathrm{Mn}, \mathrm{Fe}, \mathrm{Cu}$ and $\mathrm{Zn}$, and toxic elements: $\mathrm{Cr}, \mathrm{Ni}, \mathrm{As}$ and $\mathrm{Pb}$. In such categories, the content of particular types of biomass was considered. The statistical analysis was carried out in the Statistica program (StatSoft, Inc., Tulsa, OK, USA 2011) using hierarchical cluster analysis. Similar groups of raw materials were searched considering the content in ash of macroelements, microelements and toxic elements. The results were standardized using the Ward grouping method with Euclidean distance.

\section{Results and Discussion}

The results of investigations of ash contents and the contents of inorganic elements in the ashes, as analyzed by XRF in the examined biomass, are presented in Table 2. 
Table 2. Ash content in the biomass [\%] and chemical composition of the ashes tested (ppm).

\begin{tabular}{|c|c|c|c|c|c|c|c|c|c|c|c|c|c|c|}
\hline Code & Feature & Ash & $\mathbf{P}$ & $\mathbf{K}$ & $\mathrm{Ca}$ & $S$ & $\mathrm{Cu}$ & $\mathrm{Fe}$ & Mn & $\mathrm{Zn}$ & $\mathrm{Ni}$ & $\mathrm{Cr}$ & $\mathrm{Pb}$ & As \\
\hline \multirow{2}{*}{ I-BW } & mean & 0.67 & 20,853 & 71,290 & 132,583 & 5631 & 97.10 & 6518 & 17,585 & 212.67 & 34.91 & 39.07 & 40.48 & 1.01 \\
\hline & SD & 0.069 & 404.17 & 1370.92 & 3195.21 & 88.05 & 0.69 & 79.75 & 503.38 & 3.06 & 1.02 & 0.81 & 0.19 & 0.02 \\
\hline \multirow{2}{*}{ I-PiW } & mean & 0.59 & 18,618 & 116,436 & 201,109 & 7142 & 196.00 & 3665 & 10,693 & 193.13 & 45.84 & 62.04 & 28.89 & 1.59 \\
\hline & SD & 0.046 & 459.43 & 1419.16 & 3407.62 & 89.46 & 1.73 & 32.65 & 244.24 & 1.12 & 1.18 & 2.99 & 0.46 & 0.32 \\
\hline \multirow{2}{*}{ I-OW } & mean & 0.37 & 15,071 & 57,331 & 156,738 & 5107 & 190.67 & 9256 & 10,114 & 169.33 & 125.67 & 89.87 & 54.49 & 1.91 \\
\hline & SD & 0.008 & 52.85 & 5433.49 & 3508.10 & 317.16 & 2.31 & 183.01 & 376.43 & 6.11 & 4.04 & 1.70 & 3.86 & 0.08 \\
\hline \multirow{2}{*}{ I-HW } & mean & 0.73 & 16,548 & 69,905 & 249,050 & 3956 & 140.67 & 8598 & 18,587 & 155.00 & 158.67 & 10.65 & 40.20 & 1.13 \\
\hline & SD & 0.034 & 492.33 & 1341.71 & 517.41 & 30.81 & 30.11 & 437.53 & 631.85 & 18.45 & 8.62 & 0.28 & 3.47 & 0.05 \\
\hline \multirow{2}{*}{ I-AW } & mean & 0.43 & 17,967 & 70,442 & 279,785 & 3077 & 121.00 & 5758 & 10,545 & 183.00 & 24.84 & 30.66 & 15.31 & 0.78 \\
\hline & SD & 0.017 & 339.13 & 281.71 & 4991.02 & 32.08 & 2.00 & 56.30 & 10.00 & 2.65 & 0.47 & 0.84 & 0.17 & 0.14 \\
\hline \multirow{2}{*}{ I-WRF } & mean & 0.96 & 17,680 & 69,104 & 203,935 & 1546 & 188.00 & 3403 & 6920 & 171.00 & 110.33 & 95.64 & 50.67 & 1.44 \\
\hline & $\mathrm{SD}$ & 0.065 & 198.95 & 976.94 & 3949.64 & 204.58 & 1.00 & 33.65 & 172.42 & 1.00 & 1.15 & 2.74 & 0.53 & 0.11 \\
\hline \multirow{2}{*}{ I-WRM } & mean & 1.79 & 32,039 & 108,081 & 245,075 & 8464 & 181.00 & 4678 & 2815 & 320.33 & 176.33 & 25.00 & 12.69 & 0.13 \\
\hline & SD & 0.323 & 59.77 & 1096.39 & 5387.04 & 79.08 & 1.00 & 49.65 & 227.07 & 4.16 & 1.53 & 1.11 & 0.28 & 0.02 \\
\hline \multirow{2}{*}{ I-PoW } & mean & 0.91 & 6419 & 64,985 & 173,872 & 5015 & 96.92 & 4612 & 549.67 & 81.41 & 26.19 & 20.57 & 9.65 & 0.18 \\
\hline & SD & 0.039 & 455.55 & 57.47 & 2696.99 & 1.00 & 3.34 & 2.08 & 10.12 & 1.05 & 0.06 & 0.18 & 0.22 & 0.01 \\
\hline \multirow{2}{*}{$\mathrm{I}-\mathrm{W}$} & mean & 0.38 & 3342 & 37,339 & 135,981 & 4732 & 123.50 & 2662 & 910 & 394.00 & 32.00 & 45.97 & 8.93 & 0.34 \\
\hline & SD & 0.073 & 17.58 & 280.22 & 1052.50 & 153.52 & 0.92 & 7.23 & 11.79 & 7.81 & 0.41 & 0.20 & 0.14 & 0.04 \\
\hline \multirow{2}{*}{ I-BLW } & mean & 0.45 & 2679 & 38,799 & 227,225 & 1826 & 158.00 & 6156 & 794.33 & 244.00 & 59.72 & 36.31 & 15.83 & 0.49 \\
\hline & SD & 0.027 & 443.92 & 1088.85 & 6719.70 & 38.03 & 3.61 & 124.65 & 69.02 & 6.24 & 1.17 & 1.48 & 0.38 & 0.01 \\
\hline \multicolumn{2}{|c|}{$\mathrm{CV}[\%]$} & 58.86 & 56.99 & 34.99 & 24.25 & 45.23 & 25.59 & 38.05 & 81.76 & 40.42 & 60.60 & 61.21 & 70.57 & 67.43 \\
\hline \multirow{2}{*}{ II-VM } & mean & 3.49 & 16,777 & 139,234 & 276,611 & 13,038 & 67.89 & 5445 & 909.67 & 157.00 & 83.89 & 47.51 & 28.19 & 0.93 \\
\hline & SD & 0.090 & 349.16 & 1766.96 & 4580.64 & 137.79 & 1.47 & 92.70 & 16.77 & 3.00 & 1.74 & 0.97 & 0.54 & 0.17 \\
\hline \multirow{2}{*}{ II-JA } & mean & 3.77 & 31,990 & 154,359 & 193,316 & 7877 & 72.62 & 2536 & 143.33 & 463.67 & 35.83 & 50.61 & 6.43 & 0.32 \\
\hline & SD & 0.124 & 824.66 & 3157.97 & 3392.32 & 200.82 & 0.35 & 8.50 & 1.53 & 1.15 & 0.74 & 1.42 & 0.07 & 0.05 \\
\hline
\end{tabular}


Table 2. Cont.

\begin{tabular}{|c|c|c|c|c|c|c|c|c|c|c|c|c|c|c|}
\hline Code & Feature & Ash & $\mathbf{P}$ & $\mathbf{K}$ & $\mathrm{Ca}$ & $S$ & $\mathrm{Cu}$ & $\mathrm{Fe}$ & Mn & $\mathrm{Zn}$ & $\mathrm{Ni}$ & $\mathrm{Cr}$ & $\mathrm{Pb}$ & As \\
\hline \multirow{2}{*}{ II-MR } & mean & 3.21 & 26,246 & 139,384 & 217,339 & 6280 & 33.00 & 1875 & 788.00 & 413.00 & 52.58 & 23.14 & 6.11 & 0.36 \\
\hline & SD & 0.323 & 900.99 & 3791.34 & 5908.95 & 602.48 & 0.88 & 24.09 & 2.00 & 8.72 & 1.06 & 0.72 & 0.03 & 0.09 \\
\hline \multirow{2}{*}{ II-MG } & mean & 3.63 & 24,849 & 87,462 & 46,491 & 7510 & 70.70 & 2511 & 625.33 & 222.00 & 45.65 & 60.87 & 9.23 & 0.31 \\
\hline & SD & 0.054 & 163.72 & 962.88 & 339.15 & 65.59 & 0.10 & 25.24 & 3.06 & 2.65 & 0.29 & 0.47 & 0.14 & 0.06 \\
\hline \multirow{2}{*}{ II-MS } & mean & 3.61 & 21,323 & 49,658 & 36,409 & 2459 & 81.55 & 4464 & 529.00 & 458.00 & 51.98 & 63.77 & 7.27 & 0.39 \\
\hline & SD & 0.086 & 430.84 & 948.69 & 361.63 & 102.19 & 0.49 & 32.91 & 2.00 & 2.00 & 0.10 & 0.21 & 0.08 & 0.08 \\
\hline \multirow{2}{*}{ II-PC } & mean & 5.38 & 22,914 & 32,556 & 78,914 & 1384 & 54.99 & 4752 & 681.33 & 319.33 & 32.73 & 50.29 & 13.03 & 0.65 \\
\hline & SD & 0.260 & 706.17 & 932.43 & 1030.57 & 51.96 & 1.44 & 167.48 & 24.44 & 9.24 & 1.39 & 2.21 & 0.37 & 0.09 \\
\hline \multirow{2}{*}{ II-CR } & mean & 2.36 & 11,624 & 41,517 & 55,077 & 1135 & 44.27 & 3199 & 1146 & 582.33 & 36.10 & 44.48 & 14.65 & 0.13 \\
\hline & $\mathrm{SD}$ & 0.035 & 266.58 & 146.07 & 91.82 & 92.95 & 1.53 & 13.05 & 54.04 & 0.58 & 0.40 & 1.32 & 0.25 & 0.01 \\
\hline \multirow{2}{*}{ II-S } & mean & 7.72 & 14,949 & 53,607 & 48,367 & 2232 & 69.11 & 5371 & 1249 & 534.67 & 32.18 & 64.57 & 28.73 & 0.73 \\
\hline & $\mathrm{SD}$ & 0.117 & 484.49 & 794.36 & 322.26 & 649.55 & 2.77 & 248.86 & 78.53 & 21.94 & 1.48 & 1.04 & 0.80 & 0.11 \\
\hline \multicolumn{2}{|c|}{ CV [\%] } & 40.24 & 29.81 & 54.89 & 76.04 & 76.47 & 25.28 & 35.73 & 44.55 & 36.27 & 25.53 & 62.67 & 35.59 & 55.32 \\
\hline \multirow{2}{*}{ III-WS } & mean & 8.19 & 10,137 & 69,319 & 42,145 & 5955 & 27.84 & 4948 & 337.33 & 216.67 & 7.38 & 60.47 & 6.82 & 0.18 \\
\hline & SD & 0.212 & 157.82 & 849.32 & 611.31 & 80.55 & 0.32 & 45.83 & 4.04 & 2.08 & 0.14 & 1.92 & 0.07 & 0.07 \\
\hline \multirow{2}{*}{ III-TrS } & mean & 8.97 & 26,225 & 187,587 & 38,350 & 7772 & 43.03 & 7723 & 460.00 & 190.33 & 12.84 & 90.85 & 7.32 & 0.14 \\
\hline & $\mathrm{SD}$ & 0.321 & 146.65 & 3206.92 & 785.99 & 127.08 & 0.77 & 80.25 & 11.36 & 1.53 & 0.07 & 1.11 & 0.03 & 0.03 \\
\hline \multirow{2}{*}{ III-OS } & mean & 8.70 & 16,439 & 92,168 & 86,196 & 3415 & 22.06 & 1974 & 322.00 & 126.33 & 13.14 & 14.58 & 7.69 & 0.09 \\
\hline & SD & 0.673 & 130.31 & 939.36 & 1426.03 & 84.69 & 0.56 & 29.60 & 7.94 & 1.53 & 0.11 & 0.69 & 0.14 & 0.01 \\
\hline \multirow{2}{*}{ III-TaS } & mean & 6.88 & 21,760 & 108,603 & 84,223 & 7877 & 64.88 & 1371 & 321.00 & 388.67 & 8.84 & 20.62 & 4.39 & 0.18 \\
\hline & SD & 0.036 & 574.04 & 2752.07 & 1288.73 & 165.08 & 0.25 & 9.42 & 4.36 & 3.21 & 0.13 & 0.85 & 0.24 & 0.02 \\
\hline \multirow{2}{*}{ III-BS } & mean & 9.20 & 22,725 & 131,067 & 77,974 & 6885 & 38.78 & 2677 & 349.00 & 166.00 & 8.24 & 47.94 & 3.90 & 0.08 \\
\hline & SD & 0.132 & 272.29 & 742.94 & 106.57 & 17.24 & 0.73 & 30.27 & 4.58 & 1.00 & 0.51 & 1.90 & 0.12 & 0.01 \\
\hline \multirow{2}{*}{ III-H } & mean & 8.07 & 24,799 & 175,174 & 65,546 & 8407 & 51.31 & 2676 & 675.00 & 447.00 & 37.30 & 69.56 & 33.33 & 0.07 \\
\hline & SD & 0.084 & 74.85 & 472.58 & 247.79 & 65.29 & 0.07 & 13.75 & 1.00 & 1.73 & 0.33 & 0.90 & 2.75 & 0.01 \\
\hline
\end{tabular}


Table 2. Cont.

\begin{tabular}{|c|c|c|c|c|c|c|c|c|c|c|c|c|c|c|}
\hline Code & Feature & Ash & $\mathbf{P}$ & $\mathbf{K}$ & $\mathrm{Ca}$ & $\mathbf{S}$ & $\mathrm{Cu}$ & $\mathrm{Fe}$ & Mn & $\mathrm{Zn}$ & $\mathrm{Ni}$ & $\mathrm{Cr}$ & $\mathbf{P b}$ & As \\
\hline \multicolumn{2}{|c|}{ CV [\%] } & 10.02 & 27.84 & 34.45 & 30.11 & 25.68 & 35.48 & 62.56 & 31.95 & 47.84 & 54.29 & 100.3 & 73.05 & 42.89 \\
\hline \multirow{2}{*}{ IV-BB } & mean & 10.18 & 11,355 & 28,763 & 353,721 & 2400 & 104.00 & 4560 & 482.67 & 68.83 & 99.07 & 20.65 & 9.08 & 0.12 \\
\hline & SD & 0.126 & 859.23 & 407.75 & $14,448.62$ & 46.70 & 2.65 & 125.13 & 13.43 & 1.96 & 1.04 & 0.58 & 0.08 & 0.01 \\
\hline \multirow{2}{*}{ IV-OB } & mean & 6.27 & 3958 & 21,102 & 322,489 & 9600 & 202.67 & 3841 & 418.67 & 145.67 & 48.07 & 31.06 & 24.18 & 0.85 \\
\hline & SD & 0.037 & 312.35 & 133.84 & 4099.19 & 104.89 & 4.51 & 59.48 & 2.52 & 2.31 & 0.49 & 3.41 & 0.42 & 0.14 \\
\hline \multirow{2}{*}{ IV-HB } & mean & 9.17 & 3489 & 24,661 & 277,589 & 13,924 & 25.21 & 1088 & 313.33 & 160.33 & 68.57 & 12.49 & 11.23 & 0.13 \\
\hline & SD & 0.121 & 206.61 & 379.75 & 4727.50 & 935.15 & 0.89 & 36.10 & 42.92 & 5.03 & 2.43 & 0.10 & 0.30 & 0.01 \\
\hline \multirow{2}{*}{ IV-AB } & mean & 9.14 & 5109 & 23,185 & 311,438 & 3341 & 19.83 & 936.00 & 340.33 & 108.00 & 42.95 & 13.94 & 9.71 & 0.11 \\
\hline & SD & 0.096 & 405.12 & 1094.21 & 5794.18 & 78.70 & 0.13 & 13.86 & 9.29 & 4.36 & 0.71 & 0.45 & 0.27 & 0.01 \\
\hline \multirow{2}{*}{ IV-BLB } & mean & 10.44 & 7152 & 19,936 & 302,913 & 1724 & 61.00 & 1503 & 465.33 & 307.33 & 64.70 & 20.07 & 14.03 & 0.98 \\
\hline & SD & 0.164 & 958.96 & 127.26 & 6070.13 & 2.65 & 1.75 & 23.29 & 27.54 & 3.21 & 0.75 & 1.59 & 0.21 & 0.21 \\
\hline \multicolumn{2}{|c|}{ CV [\%] } & 32.04 & 48.49 & 13.72 & 8.50 & 79.91 & 84.30 & 65.59 & 17.88 & 53.17 & 35.37 & 42.04 & 31.62 & 94.90 \\
\hline \multirow{2}{*}{$\mathrm{V}-\mathrm{CP}$} & mean & 1.06 & 9450 & 193,663 & 91,717 & 14,482 & 795.33 & 9281 & 705.33 & 826.33 & 40.23 & 65.53 & 12.35 & 1.58 \\
\hline & SD & 0.050 & 118.07 & 3729.06 & 2385.99 & 63.51 & 11.15 & 145.57 & 20.26 & 11.37 & 0.40 & 1.54 & 0.07 & 0.11 \\
\hline \multirow{2}{*}{ V-SH } & mean & 2.94 & 27,752 & 141,783 & 190,313 & 9734 & 91.72 & 3096 & 380.67 & 146.00 & 22.23 & 21.18 & 4.42 & 0.09 \\
\hline & SD & 0.14 & 428.64 & 1806.89 & 3094.12 & 117.63 & 0.75 & 31.90 & 8.14 & 1.73 & 0.82 & 0.90 & 0.10 & 0.00 \\
\hline \multirow{2}{*}{ V-RP } & mean & 9.18 & 14,151 & 129,477 & 277,338 & 6063 & 33.18 & 1573 & 269.00 & 45.70 & 23.76 & 18.82 & 3.82 & 0.09 \\
\hline & SD & 0.324 & 175.12 & 895.40 & 2094.17 & 21.42 & 0.22 & 9.29 & 3.00 & 0.44 & 0.52 & 0.12 & 0.11 & 0.00 \\
\hline \multirow{2}{*}{ V-AP } & mean & 3.32 & 33,208 & 143,679 & 184,430 & 19,128 & 582.00 & 1716 & 345.67 & 492.33 & 64.33 & 10.67 & 13.82 & 1.72 \\
\hline & SD & 0.266 & 176.21 & 3637.03 & 400.83 & 64.50 & 24.56 & 155.18 & 8.39 & 29.02 & 5.64 & 0.81 & 1.23 & 0.42 \\
\hline \multirow{2}{*}{ V-HS } & mean & 5.04 & 15,674 & 184,542 & 109,089 & 9216 & 465.00 & 2144 & 118.33 & 325.33 & 61.64 & 37.62 & 7.56 & 0.13 \\
\hline & SD & 0.49 & 308.51 & 5158.78 & 4452.17 & 66.43 & 19.29 & 81.22 & 1.53 & 12.74 & 1.90 & 1.35 & 0.19 & 0.03 \\
\hline \multirow{2}{*}{ V-WS } & mean & 3.76 & 11,981 & 185,001 & 72,773 & 4391 & 202.75 & 1108 & 123.25 & 89.21 & 42.04 & 50.93 & 6.51 & 0.12 \\
\hline & SD & 0.18 & 164.99 & 1297.41 & 405.22 & 3.79 & 0.96 & 3.00 & 0.50 & 0.13 & 0.05 & 1.25 & 0.10 & 0.02 \\
\hline \multicolumn{2}{|c|}{ CV [\%] } & 65.31 & 47.77 & 16.06 & 47.12 & 48.92 & 78.25 & 91.66 & 62.91 & 87.41 & 58.29 & 48.38 & 40.08 & 123.1 \\
\hline
\end{tabular}


Ash content in biomass is a complex problem. The amount of ash depends on the content of organic and inorganic matter and possible impurities. The ash content in biomass depends on the sampling point, harvesting time, and harvest conditions. In the examined biomass the ash content was typical for this raw material [21,22] and ranged from 0.37 to $10.44 \%$. The lowest ash content was found in the biomass from Group I (WWB) below 1\%-with the exception of Wood residue chips (municipal), the density of which amounted to $1.79 \%$, which could be due to the high pollution with mineral compounds. The variability of ash content in this group was high (CV-58.86\%). In the remaining groups the ash content varied within quite wide limits. In Group II (EC) the ash content was in the range of $2.36 \%$ for the Common reed to $5.38 \%$ for Switchgrass, content variability was determined to be high (CV-40.24\%). The Group III agricultural biomass (AB) was characterized with an average ash content and a fairly small spread of the results of 6.88 to $9.2 \%$, in this group the variability of ash content was defined as low CV-10.02\%. A higher ash content was observed in Group IV Forest Residue FR (6.27-10.44\%), and the variability was determined as average. The largest spread of results occurred in Group V Agri-Food Industry Wastes (AFIW) from $1.06 \%$ for Cherry pits to $9.98 \%$ for Sunflower husks, and the variability was determined to be high: CV-65.31\%. Information on ash content in biomass along with information on fuel can be used to estimate the total amount of ash produced during the combustion of biomass fuels. However, it should be taken into account that these quantities may be higher due to the possible low effectiveness of boilers.

From the point of view of the assessment of the suitability of biomass as a fuel, the compactness of ash is significant. It was shown that the calorific value was negatively related to the ash content, with each increase in the ash percentage by $1 \%$, the calorific value was reduced by $0.2 \mathrm{MJ} \cdot \mathrm{kg}^{-1}$ [23].

The content of individual elements in the examined ash was very diverse (Table 2). In the ashes from the I-WWB group, the highest content of $\mathrm{P}$ was found in the ash from Wood residue chips-municipal and the lowest from Acacia wood and in this group the highest variability was noted (CV-56.99\%). In group II-EC, the highest content of this element was recorded in Jerusalem artichoke ash and the lowest in the ash from Common reed. In group III-AB, the most P was contained in the ash from Triticale straw and Hay and the least from Oat straw; in both the groups the average variability of ash content was noted. In the IV-FR group, the highest $P$ content was recorded in the ash from Acacia bark, the lowest from Oak bark and Hornbeam bark, while in the V-AFIW group, the most $P$ was contained in Apple pomace ash, the least in Walnut shell one, in these groups there was a high variability of ash content.

The content of K in the ashes of I-WWB group was the highest in the ash from Wood residue chips -municipal and Birch wood, and the lowest from Willow and Acacia wood, the variability of $\mathrm{K}$ content in this group was average. In group II-EC, with a high variability of content $K$, the most of this element was in the ash from Jerusalem artichoke, the least from Common reed. In the ashes of the III-AB group, with average variability of $K$ content, the most $K$ was found in the ash from Triticale straw, the least from Barley straw and Oat straw. In the IV-FR group, the content of K was the most homogenous; most of it was contained in the ash from Acacia bark, the least from Hornbeam bark. In the V-AFIW group, the highest content of the element in question was determined in the ash from Cherry pits, the lowest from Rape pods. These were the groups with low variability of K content.

The $\mathrm{S}$ content was clearly differentiated in all the groups, in the I-WWB group the highest $\mathrm{S}$ content was found in the ash from Wood residue chips-municipal-and the lowest from Acacia wood and Wood residue chips-forest. In group II-EC, the highest $S$ content was found in the ash from Virginia mallow, the least in the ashes from Prairie cordgrass and Common reed, while in group IV-FR the most $\mathrm{S}$ was found in the ashes from Hornbeam shoulder and the least from Acacia bark, and in group V-AFIW, the highest S-content was found in the ashes from Apple pomace and the least from Walnut shell. In these groups there was a high variability in the content of this element (CV-above $70 \%$ ). In group III-AB, the highest $\mathrm{S}$ content was found in the ash from Hay and the lowest from Oak bark, at the same time it was the group with average variability of content $\mathrm{S}$. 
In the ashes from the I-WWB group, containing the most $\mathrm{Cu}$, the highest content of this element was found in the ash from Pine wood, Oak wood and Wood residue chips-forest, the lowest from Birch wood and Poplar wood. In group II-EC, the most $\mathrm{Cu}$ was found in the ashes from Miscanthus sacchariflorus and Jerusalem artichoke, the least in the ash from Multiflorous rose. In group III-AB the highest $\mathrm{Cu}$ content was determined in the ash from Barley straw, the lowest in the ash from Oat straw. These were the groups with the average variability of $\mathrm{Cu}$ content. In turn, in the IV-FR group, the majority of this element was found in Oak bark ash and the lowest in Ash bark, while in the V-AFIW group the most $\mathrm{Cu}$ was in the ash from Cherry pits and the least from Rape pods, these were the groups with high variability of $\mathrm{Cu}$ content (CV-about $80 \%)$.

In the raw materials from the I-WWB group, the highest Fe content was found in the ashes from Oak wood and Hornbeam and the lowest from Willow, in group II-EC the highest density of this element was observed in the ashes from Virginia mallow and Miscanthus sacchariflorus and the lowest from Multiflorous rose. These were the groups with the average variability of Fe content. In group III-AB, the most Fe was contained in the ash from Triticale straw and the least from Barley straw. In the IV-FR group the highest Fe content was recorded in Oak bark ash, the lowest in Ash bark ash, while in the V-AFIW group the most Fe was contained in the ash from Sunflower husk and the least from Walnut shell. In these groups there was a high variability of Fe content.

Groups I-WWB, II-EC and V-AFIW are included in the groups with high variability of Mn. In group I-WWB, the highest Mn content was found in the ashes from Hornbeam wood and Birch wood and the lowest from Poplar wood, moreover, Mn content in this group was very diverse. In group II-EC the highest Mn content was found in the ash from Switchgrass and Common reed, the lowest in the ash from Jerusalem artichoke, while in group V-AFIW, the most of this element was found in the ashes from Sunflower husk and the least from Walnut and Hazelnut shell. In group III-AB, with an average variability of Mn content, the highest Mn content was found in the ash from Hay and the lowest from Oat straw and Barley straw. In group IV-FR, the most Mn was found in the ash from Acacia bark and the least in the ash from Hornbeam bark, this group had low variability in Mn content.

The $\mathrm{Zn}$ content was also clearly different in all the groups, in the I-WWB group, the highest Zn content was found in the ashes from Willow and Wood residue chips-municipal-and the lowest from Poplar wood. In group II-EC, the highest Zn content was in the ash from Common reed and Switchgrass, the least in the ash from Virginia mallow. These were the groups with average variability in $\mathrm{Zn}$ content. In group III-AB, the highest $\mathrm{Zn}$ content was found in the ash from Hay and the lowest from Oat straw. In the IV-FR group, the most $Z n$ was found in the ash from Acacia bark and the least from Ash bark, and in the V-AFIW group, the highest content of $\mathrm{Zn}$ was found in Cherry seed ash and the least from Rape pods. In these groups a high variability of $Z n$ content was noted.

Also, $\mathrm{Ni}$ and $\mathrm{Cr}$ content varied in all the groups. In the I-WWB group, with high variability of $\mathrm{Ni}$ content, the highest Ni content was found in the ash from Wood residue chips-municipal—and the lowest from Poplar wood and Ash wood. In group II-EC, its highest content was found in the ash from Virginia mallow, whereas the lowest in the ash from Switchgrass and Prairie cordgrass. It was the group with the average variability of Ni content. In group III-AB, also characterized by the high variability of Ni content, the highest content of this element was found in the ash from Hay and the lowest from Buckwheat straw. In IV-FR and V-AFIW groups, average variability of Ni content was found. In the IV-FR group, the most $\mathrm{Ni}$ was found in the ash from Hornbeam bark and the least from Ash bark, while in V-AFIW group, the most Ni was found in the ashes from Apple pomace and the least from Sunflower husk.

The variability in Cr content was high for groups I-WWB, III-AB, and V-AFIW. In I-WWB, the highest $\mathrm{Cr}$ content was determined in the ash from Wood residue chips-forest-the lowest in Hornbeam wood ash. While in III-AB, the highest content of this element was found in the ash from Triticale straw, the lowest from Oat straw, and in group V-AFIW the most $\mathrm{Cr}$ was found in the ash from Walnut shell and the least in the ash from Apple pomace. In group II-EC, the highest content of Cr was found in the ashes from Miscanthus sacchariflorus and Switchgrass, and the lowest from Multiflorous 
rose. In group IV-FR, the highest content of this element was determined in Oak bark ash, with the lowest in Ash bark and Hornbeam bark ashes. These were the groups with the average variability of Cr content.

The variability of $\mathrm{Pb}$ and As contents was high and very high, respectively. The highest $\mathrm{Pb}$ content in the I-WWB group was found in Oak wood and Wood residue chips-forest-the lowest in this group was in the ashes from Poplar wood and Willow. In group II-EC, the highest content of this element was found in the ashes from Virginia mallow and Switchgrass, and the lowest from Jerusalem artichoke and Multiflorous rose. In group III- $\mathrm{AB}$, the highest $\mathrm{Pb}$ content was found in the ash from Hay and the lowest from Buckwheat straw; this group had very high variability in Pb content. In the IV-FR group, the most $\mathrm{Pb}$ was found in Oak bark ash, the least in Ash bark ash. Among the raw materials included in the V-AFIW group, the most $\mathrm{Pb}$ was contained in the ash from Apple pomace and the least from Rape pods.

The content of As in all the designated groups of raw materials was the lowest of the analyzed elements. The content of this element in the ashes from group I-WWB was the highest in the ash from Oak wood, and the lowest from Poplar wood and Wood residue chips-municipal. In group II-EC, the highest As content was in the ash from Virginia mallow, the lowest from the Common reed. In the ashes of the III-AB group, the most As was found in the ash from Barley straw, the least in the ashes from Oat straw, Buckwheat straw, and Hay. In the IV-FR group, the most As was contained in the ash from Acacia bark, the least from Ash bark. In the V-AFIW group, the highest As content was determined in the Apple pomace ash, the lowest in the ashes from Rape pods and Hazelnut shell, at the same time this group had a very high variability of $\mathrm{Pb}$ content.

In order to check whether the adopted division of biomass into groups due to its origin is also reflected in the chemical composition of the ashes examined, statistical analysis of the results obtained was carried out. This analysis was carried out taking into consideration the contents in ash of macronutrients $(\mathrm{P}, \mathrm{K}, \mathrm{Ca}$ and $\mathrm{S})$, microelements $(\mathrm{Cu}, \mathrm{Fe}, \mathrm{Mn}$ and $\mathrm{Zn})$, and toxic elements $(\mathrm{As}, \mathrm{Pb}, \mathrm{Ni}$ and $\mathrm{Cr}$ ).

When performing the statistical analysis looking for similar groups of raw materials in terms the content of macroelements in their ashes, a division into three groups of raw materials was obtained (Figure 1a). The smallest and most homogeneous group was made up of Wheat straw, Switchgrass, Common reed, Prairie cordgrass, Miscanthus sacchariflorus, Oat straw, Oak and Birch wood. These were raw materials with moderate $\mathrm{P}$ and $\mathrm{K}$ contents as well as low and moderate $\mathrm{Ca}$ and $\mathrm{S}$ contents, respectively. The second group consisted of the following raw materials, Hornbeam bark, Oak bark, Acacia bark, Ash bark, Beech bark, Willow, Poplar, Forest chips, Ash wood and Hornbeam wood, which showed low values of $K$. The remaining raw materials were classified in the third group, which contained moderate and the highest values of $\mathrm{P}$ and $\mathrm{K}$.

The division of biomass due to its origin was not reflected in the content of macroelements in ashes from this biomass. The only homogeneous group was the first one, which included forest waste in the form of bark and wood biomass. The materials tested involved three groups that contained mixed materials of different origins.

When looking for similar groups of raw materials in terms of the content of their ashes of the $\mathrm{Cu}$, $\mathrm{Fe}, \mathrm{Mn}$ and $\mathrm{Zn}$ microelements, five groups were obtained (Figure 1b). In the first group (Hazelnut shell, Apple pomace and Cherry pits) the highest $\mathrm{Cu}$ content was observed, in the second group the following raw materials were found, Common reed, Switchgrass, Miscanthus sacchariflorus, Acacia bark, Barley straw, Floral rose, Hay, Jerusalem artichoke and Willow. The most homogeneous was the third group containing Walnut shell, Rape pods, Ash and Hornbeam bark, Oat and Buckwheat straw, Sunflower husk and Gigantic miscanthus. The fourth group consisted of Oak bark, Beech bark, Poplar wood, Triticale straw, Wheat straw, Virginia mallow, Acacia wood, Prairie cordgrass, as well as Municipal chips. The fifth group included Ash wood, Forest chips, Pine, Oak, Hornbeam and Birch wood; in these raw materials the highest Mn content was recorded. 


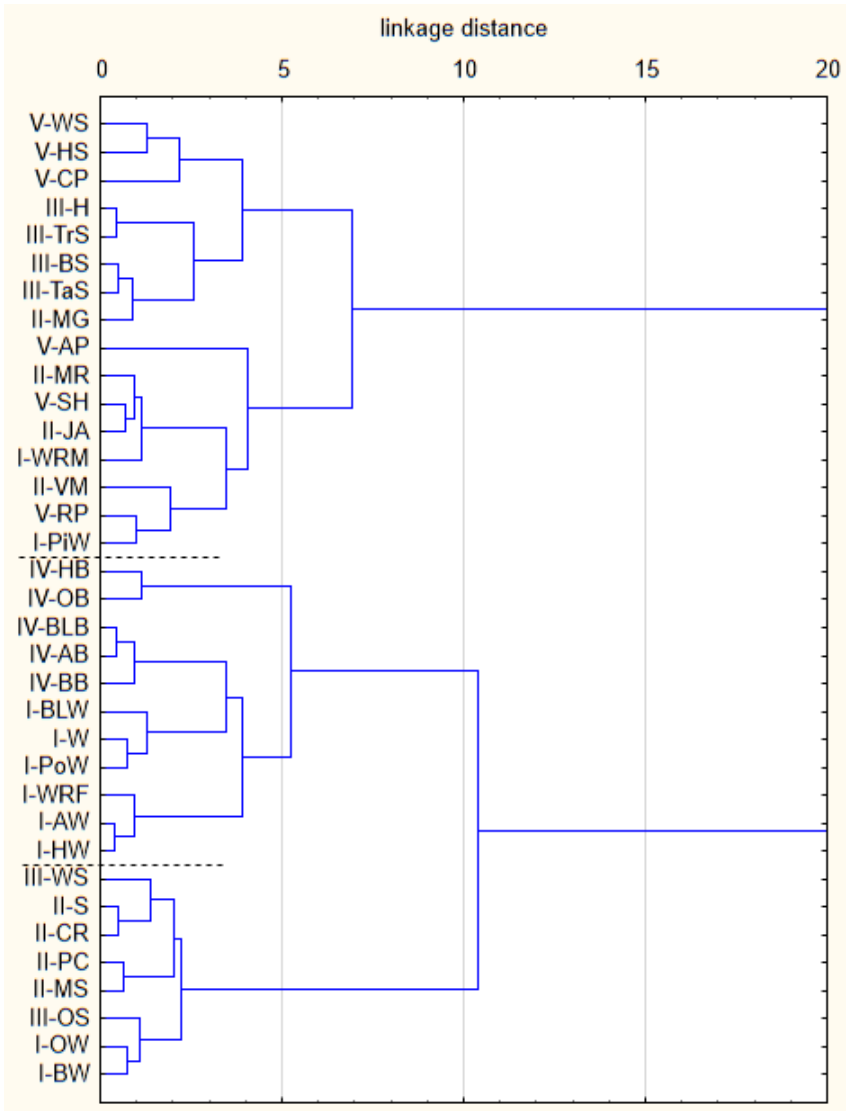

(a)

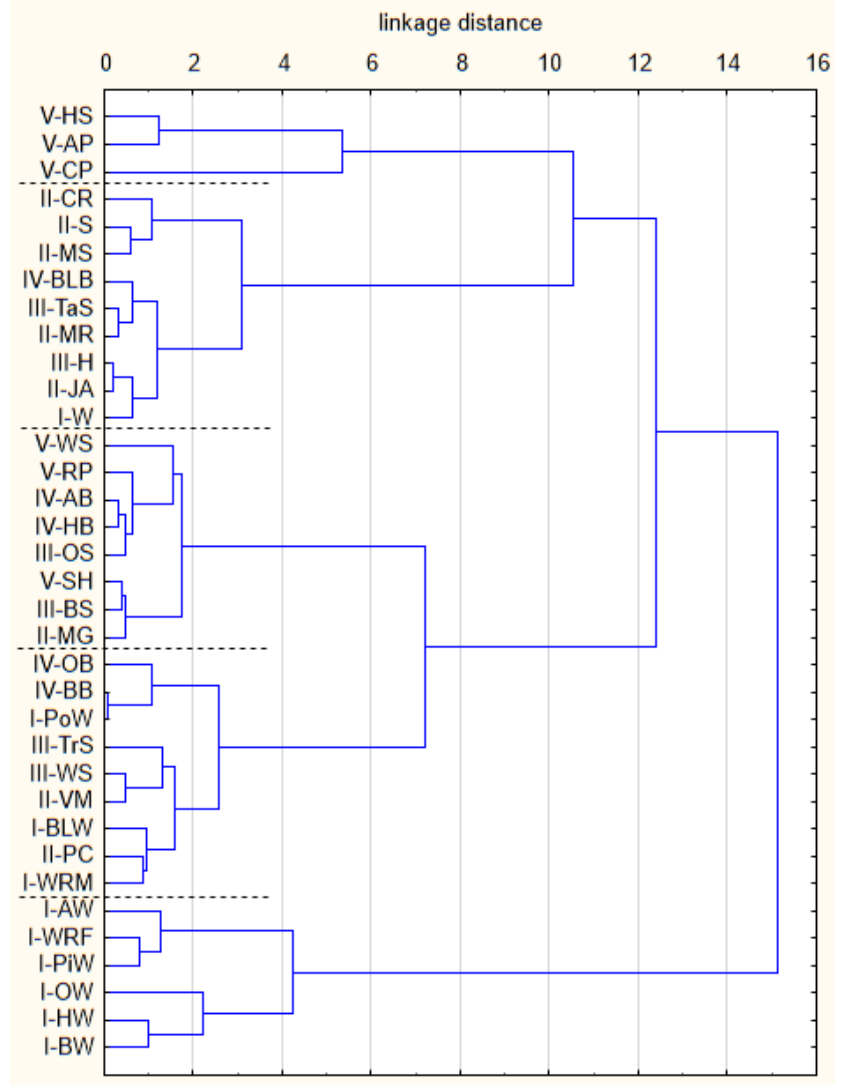

(b)

Figure 1. Cont. 


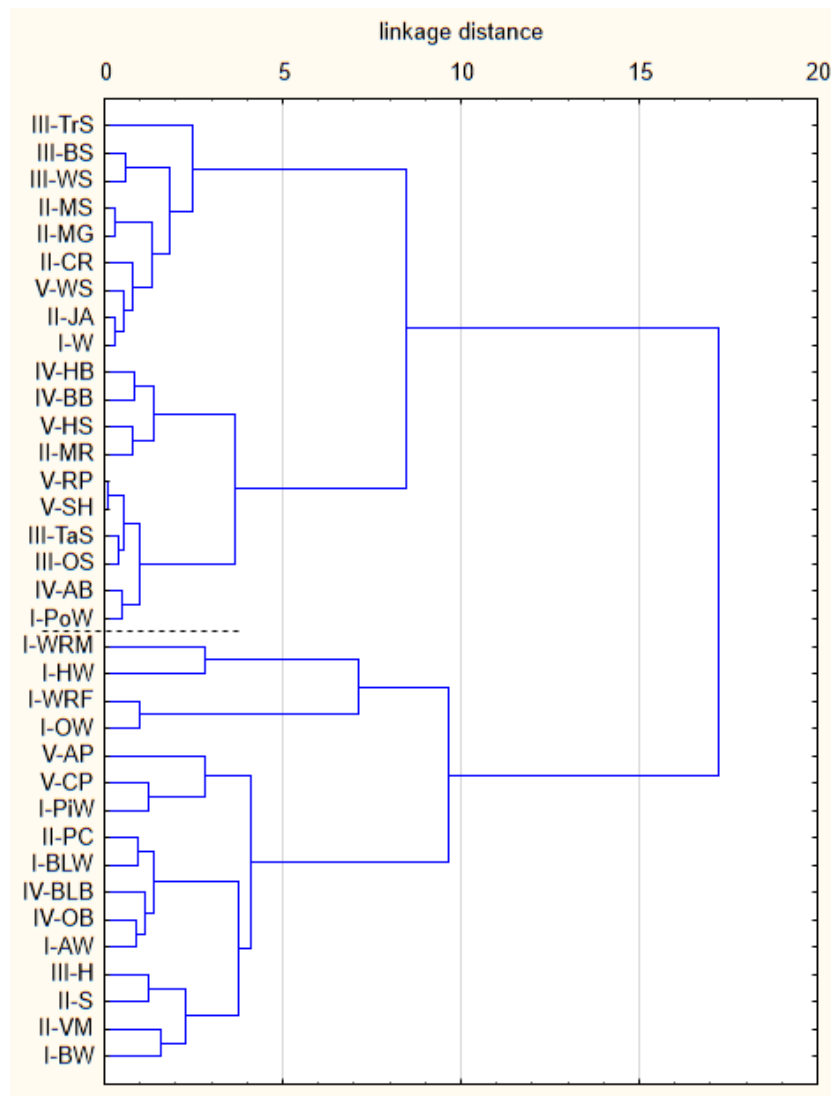

(c)

Figure 1. Dendrogram with the division of raw materials due to the contents of (a) $\mathrm{P}, \mathrm{K}, \mathrm{Ca}, \mathrm{S}$; (b), Cu, $\mathrm{Fe}, \mathrm{Mn}, \mathrm{Zn}$; and (c) As, Pb, Ni, Cr.

When looking for similar groups of raw materials in terms of the content of their ashes of heavy metals $\mathrm{As}, \mathrm{Pb}, \mathrm{Ni}$, and $\mathrm{Cr}$, two very diverse groups of raw materials were distinguished (Figure 1c). One group included Municipal chips, Hornbeam, Forest chips, Oak, Apple pomace, Cherry pits, pine, Prairie cordgrass, Acacia wood, Acacia bark, Oak bark, Ash, Hay, Switchgrass, Virginia mallow and Birch wood. These raw materials had medium and higher $\mathrm{Pb}$ and $\mathrm{Ni}$ contents. The remaining raw materials were qualified to the next group, characterized by low content of $\mathrm{As}$ and $\mathrm{Pb}$ as well as low and moderate Ni content.

Considering the content of toxic elements in the ashes from the examined biomass, there was no relationship between the origin of biomass and the content of these elements in the ash.

The predominant components of ashes from biomass combustion were the macroelements $\mathrm{Ca}, \mathrm{P}$, $\mathrm{K}$ and, to a lesser extent, $\mathrm{S}$. The $\mathrm{K}$ content was the highest in agri-food industry waste V-AFIW, Ca in forest waste IV-FR and P in agri-food industry waste V-AFIW and energy crops II-EC, similar to the content of S.

All the ashes of biomass were enriched with microelements such as $\mathrm{Zn}, \mathrm{Cu}, \mathrm{Fe}$ and $\mathrm{Mn}$. The $\mathrm{Mn}$ content was the highest in wood biomass I-WWB, $\mathrm{Zn}$ in energy plants II-EC and agri-food industry waste V-AFIW, while $\mathrm{Cu}$ content was the highest in V-AFIW and I-WWB ash.

The content of heavy metals in biomass ash was varied. Ashes from wood biomass were characterized by the highest content of $\mathrm{As}, \mathrm{Pb}, \mathrm{Ni}$ and $\mathrm{Cr}$; this was mainly due to the longer period of wood growth, which resulted in a greater accumulation of metals. Therefore, it should be kept in mind that the impact of ashes from the combustion of wood biomass by introducing heavy metal elements into the soil may be significant. 
Száková et al. [24] determined the content of individual elements in the ash from the commercial combustion of biomass (wood chips and wood waste) using, among other techniques, X-ray fluorescence spectrometry (XRF). The compactness of the analyzed elements determined by the XRF method, given in the above-mentioned work, differed and amounted to (in ppm) P: 5300-10,800; S: 1200-11,100; K: 38,000-58,000; Ca: 78,000-159,000; Cr: 118; Mn: 6200-10,700; Fe: 29,300-34,800; N: 28.9; Cu: 153; Zn: 300-1100; As: 9.8 and Pb: 313. However, in the work by Vassiliev et al. [17] the content of the examined elements in the ash from various types of biomass was (in ppm): P from 2299 in rice husk ash to 21,001 in sunflower husk ash (average 10,439); S from 2000 in beech wood chips ash to 98,400 in the ash from marine macroalgae (average 21,700); $\mathrm{K}$ from 30,200 in the ash from rice husks to 302,900 in sunflower husk ash (average 151,100); Ca from 8800 in rice husk ash to 289,600 in the ash from beech wood chips (average 110,800); Cr from 24 in the ash from beech wood chips to 1504 in the ash from sunflower husks (average 384); Mn from 202 in the ash from nut shells to 10,595 in the ash from beech wood chips (average 1862); Fe from 1600 in the ash from beech wood chips to 6800 in the ash from sunflower husks (average 4000); $N$ from 37 in the ash from grass plants to 574 in sunflower husk ash (average 151); $\mathrm{Cu}$ from 36 in the ash from marine macroalgae to 636 in the ash from plum pits (average 232), $\mathrm{Zn}$ from 52 in the ash from marine macroalgae to 1232 in the ash from corn cobs (average 366), As from 2.6 in the ash from plum pits to 9.4 in the ash from rice husks and grass plants (average 6.3); and $\mathrm{Pb}$ from 1.5 in the ash from sunflower husk to 68.3 in the ash from corn cobs (average 20.7).

The problems of the chemical composition of ashes from various biomass species were also widely discussed [25-31].

The high variability of the content of the analyzed elements in the examined ash causes that the ash from each type of biomass must be thoroughly analyzed before its recommendation for fertilizing purposes. In order to facilitate such an analysis, the raw materials were ranked according to the decreasing content of the elements studied. The ranked-tested raw materials, in terms of decreasing content in their ashes of the particular elements analyzed, are presented in Table 3 (codes of origin groups in Table 1).

From the series it can be seen that there were mostly calcium-potassium-phosphorus ashes, $\mathrm{Ca}-\mathrm{P}-\mathrm{K}$, or potassium-calcium-phosphorus ashes, $\mathrm{K}-\mathrm{Ca}-\mathrm{P}$. The content of toxic elements (As and $\mathrm{Pb}$ ) was the lowest and these elements were included at the end of the series, with a few exceptions, such as where $\mathrm{Pb}$ was the third from the bottom (the hornbeam wood ash and apple pomace ash). The ashes from Group I-WWB were calcium-phosphorus-potassium-Ca-K-P ashes, except for hornbeam, where a higher content of Mn was found, Willow with a higher S content, and Acacia wood ashes, where the highest Fe content was found. In the II-EC group, both Ca-P-K and K-Ca-P were observed. The most similar ranks of elements were found in Group III-AB, where only $\mathrm{Cr}$ and $\mathrm{Cu}$ changed their position in the particular series. These were the K-Ca-P potassium-calcium-phosphorus ashes. Closer ranks were observed in Group IV-FR, the higher Ni content than in the ash from the other groups deserves attention. Group V-AWIF, was the most diverse in terms of ranks, which resulted from different origins of raw materials. A similar series was presented by Tsuchiya et al. [32], who described the content of inorganic elements in wood used for energy purposes. In almost all parts of the trees the main components were $\mathrm{Ca}>\mathrm{K}>\mathrm{Mg}>\mathrm{S}>\mathrm{P}$.

From the point of view of biomass combustion for energy purposes, the high content of $\mathrm{K}$ and $\mathrm{Ca}$ is unfavorable, as they easily react with other elements (e.g., Si) to form alkali with very low melting points (ca. $700{ }^{\circ} \mathrm{C}$ ). Increased $\mathrm{K}$ content may increase the slag potential of deposits [33]. Whereas ashes with less alkali and with higher Ca contents exhibit more manageable slagging, fouling, and corrosion problems. 
Table 3. The analyzed elements ranked by decreasing content in the examined ashes.

\begin{tabular}{|c|c|}
\hline Code & Elements in Decreasing Order \\
\hline I-BW & $\mathrm{Ca}>\mathrm{K}>\mathrm{P}>\mathrm{Mn}>\mathrm{Fe}>\mathrm{S}>\mathrm{Zn}>\mathrm{Cu}>\mathrm{Pb}>\mathrm{Cr}>\mathrm{Ni}>\mathrm{As}$ \\
\hline I-PiW & $\mathrm{Ca}>\mathrm{K}>\mathrm{P}>\mathrm{Mn}>\mathrm{S}>\mathrm{Fe}>\mathrm{Cu}>\mathrm{Zn}>\mathrm{Cr}>\mathrm{Ni}>\mathrm{Pb}>\mathrm{As}$ \\
\hline $\mathrm{I}-\mathrm{OW}$ & $\mathrm{Ca}>\mathrm{K}>\mathrm{P}>\mathrm{Mn}>\mathrm{Fe}>\mathrm{S}>\mathrm{Cu}>\mathrm{Zn}>\mathrm{Ni}>\mathrm{Cr}>\mathrm{Pb}>\mathrm{As}$ \\
\hline $\mathrm{I}-\mathrm{HW}$ & $\mathrm{Ca}>\mathrm{K}>\mathrm{Mn}>\mathrm{P}>\mathrm{Fe}>\mathrm{S}>\mathrm{Ni}>\mathrm{Zn}>\mathrm{Cu}>\mathrm{Pb}>\mathrm{Cr}>\mathrm{As}$ \\
\hline $\mathrm{I}-\mathrm{AW}$ & $\mathrm{Ca}>\mathrm{K}>\mathrm{P}>\mathrm{Mn}>\mathrm{Fe}>\mathrm{S}>\mathrm{Zn}>\mathrm{Cu}>\mathrm{Cr}>\mathrm{Ni}>\mathrm{Pb}>\mathrm{As}$ \\
\hline I-WRF & $\mathrm{Ca}>\mathrm{K}>\mathrm{P}>\mathrm{Mn}>\mathrm{Fe}>\mathrm{S}>\mathrm{Cu}>\mathrm{Zn}>\mathrm{Ni}>\mathrm{Cr}>\mathrm{Pb}>\mathrm{As}$ \\
\hline I-WRM & $\mathrm{Ca}>\mathrm{K}>\mathrm{P}>\mathrm{S}>\mathrm{Fe}>\mathrm{Mn}>\mathrm{Zn}>\mathrm{Cu}>\mathrm{Ni}>\mathrm{Cr}>\mathrm{Pb}>\mathrm{As}$ \\
\hline I-PoW & $\mathrm{Ca}>\mathrm{K}>\mathrm{P}>\mathrm{S}>\mathrm{Fe}>\mathrm{Mn}>\mathrm{Cu}>\mathrm{Zn}>\mathrm{Ni}>\mathrm{Cr}>\mathrm{Pb}>\mathrm{As}$ \\
\hline $\mathrm{I}-\mathrm{W}$ & $\mathrm{Ca}>\mathrm{K}>\mathrm{S}>\mathrm{P}>\mathrm{Fe}>\mathrm{Mn}>\mathrm{Zn}>\mathrm{Cu}>\mathrm{Cr}>\mathrm{Ni}>\mathrm{Pb}>\mathrm{As}$ \\
\hline I-BLW & $\mathrm{Ca}>\mathrm{K}>\mathrm{Fe}>\mathrm{P}>\mathrm{S}>\mathrm{Mn}>\mathrm{Zn}>\mathrm{Cu}>\mathrm{Ni}>\mathrm{Cr}>\mathrm{Pb}>\mathrm{As}$ \\
\hline II-VM & $\mathrm{Ca}>\mathrm{K}>\mathrm{P}>\mathrm{S}>\mathrm{Fe}>\mathrm{Mn}>\mathrm{Zn}>\mathrm{Ni}>\mathrm{Cu}>\mathrm{Cr}>\mathrm{Pb}>\mathrm{As}$ \\
\hline II-JA & $\mathrm{Ca}>\mathrm{K}>\mathrm{P}>\mathrm{S}>\mathrm{Fe}>\mathrm{Zn}>\mathrm{Mn}>\mathrm{Cu}>\mathrm{Cr}>\mathrm{Ni}>\mathrm{Pb}>\mathrm{As}$ \\
\hline II-MR & $\mathrm{Ca}>\mathrm{K}>\mathrm{P}>\mathrm{S}>\mathrm{Fe}>\mathrm{Mn}>\mathrm{Zn}>\mathrm{Ni}>\mathrm{Cu}>\mathrm{Cr}>\mathrm{Pb}>\mathrm{As}$ \\
\hline II-MG & $\mathrm{K}>\mathrm{Ca}>\mathrm{P}>\mathrm{S}>\mathrm{Fe}>\mathrm{Mn}>\mathrm{Zn}>\mathrm{Cu}>\mathrm{Cr}>\mathrm{Ni}>\mathrm{Pb}>\mathrm{As}$ \\
\hline II-MS & $\mathrm{K}>\mathrm{Ca}>\mathrm{P}>\mathrm{Fe}>\mathrm{S}>\mathrm{Mn}>\mathrm{Zn}>\mathrm{Cu}>\mathrm{Cr}>\mathrm{Ni}>\mathrm{Pb}>\mathrm{As}$ \\
\hline II-PC & $\mathrm{Ca}>\mathrm{K}>\mathrm{P}>\mathrm{Fe}>\mathrm{S}>\mathrm{Mn}>\mathrm{Zn}>\mathrm{Cu}>\mathrm{Cr}>\mathrm{Ni}>\mathrm{Pb}>\mathrm{As}$ \\
\hline $\mathrm{II}-\mathrm{CR}$ & $\mathrm{Ca}>\mathrm{K}>\mathrm{P}>\mathrm{Fe}>\mathrm{Mn}>\mathrm{S}>\mathrm{Zn}>\mathrm{Cr}>\mathrm{Cu}>\mathrm{Ni}>\mathrm{Pb}>\mathrm{As}$ \\
\hline II-S & $\mathrm{K}>\mathrm{Ca}>\mathrm{P}>\mathrm{Fe}>\mathrm{S}>\mathrm{Mn}>\mathrm{Zn}>\mathrm{Cu}>\mathrm{Cr}>\mathrm{Ni}>\mathrm{Pb}>\mathrm{As}$ \\
\hline III-WS & $\mathrm{K}>\mathrm{Ca}>\mathrm{P}>\mathrm{S}>\mathrm{Fe}>\mathrm{Mn}>\mathrm{Zn}>\mathrm{Cr}>\mathrm{Cu}>\mathrm{Ni}>\mathrm{Pb}>\mathrm{As}$ \\
\hline III-TrS & $\mathrm{K}>\mathrm{Ca}>\mathrm{P}>\mathrm{S}>\mathrm{Fe}>\mathrm{Mn}>\mathrm{Zn}>\mathrm{Cr}>\mathrm{Cu}>\mathrm{Ni}>\mathrm{Pb}>\mathrm{As}$ \\
\hline III-OS & $\mathrm{K}>\mathrm{Ca}>\mathrm{P}>\mathrm{S}>\mathrm{Fe}>\mathrm{Mn}>\mathrm{Zn}>\mathrm{Cu}>\mathrm{Cr}>\mathrm{Ni}>\mathrm{Pb}>\mathrm{As}$ \\
\hline III-TaS & $\mathrm{K}>\mathrm{Ca}>\mathrm{P}>\mathrm{S}>\mathrm{Fe}>\mathrm{Zn}>\mathrm{Mn}>\mathrm{Cu}>\mathrm{Cr}>\mathrm{Ni}>\mathrm{Pb}>\mathrm{As}$ \\
\hline III-BS & $\mathrm{K}>\mathrm{Ca}>\mathrm{P}>\mathrm{S}>\mathrm{Fe}>\mathrm{Mn}>\mathrm{Zn}>\mathrm{Cr}>\mathrm{Cu}>\mathrm{Ni}>\mathrm{Pb}>\mathrm{As}$ \\
\hline III-H & $\mathrm{K}>\mathrm{Ca}>\mathrm{P}>\mathrm{S}>\mathrm{Fe}>\mathrm{Mn}>\mathrm{Zn}>\mathrm{Cr}>\mathrm{Cu}>\mathrm{Ni}>\mathrm{Pb}>\mathrm{As}$ \\
\hline IV-BB & $\mathrm{Ca}>\mathrm{K}>\mathrm{P}>\mathrm{Fe}>\mathrm{S}>\mathrm{Mn}>\mathrm{Cu}>\mathrm{Ni}>\mathrm{Zn}>\mathrm{Cr}>\mathrm{Pb}>\mathrm{As}$ \\
\hline IV-OB & $\mathrm{Ca}>\mathrm{K}>\mathrm{S}>\mathrm{P}>\mathrm{Fe}>\mathrm{Mn}>\mathrm{Cu}>\mathrm{Zn}>\mathrm{Ni}>\mathrm{Cr}>\mathrm{Pb}>\mathrm{As}$ \\
\hline IV-HB & $\mathrm{Ca}>\mathrm{K}>\mathrm{S}>\mathrm{P}>\mathrm{Fe}>\mathrm{Mn}>\mathrm{Zn}>\mathrm{Ni}>\mathrm{Cu}>\mathrm{Cr}>\mathrm{Pb}>\mathrm{As}$ \\
\hline IV-AB & $\mathrm{Ca}>\mathrm{K}>\mathrm{P}>\mathrm{S}>\mathrm{Fe}>\mathrm{Mn}>\mathrm{Zn}>\mathrm{Ni}>\mathrm{Cu}>\mathrm{Cr}>\mathrm{Pb}>\mathrm{As}$ \\
\hline IV-BLB & $\mathrm{Ca}>\mathrm{K}>\mathrm{P}>\mathrm{S}>\mathrm{Fe}>\mathrm{Mn}>\mathrm{Zn}>\mathrm{Ni}>\mathrm{Cu}>\mathrm{Cr}>\mathrm{Pb}>\mathrm{As}$ \\
\hline $\mathrm{V}-\mathrm{CP}$ & $\mathrm{K}>\mathrm{Ca}>\mathrm{S}>\mathrm{P}>\mathrm{Fe}>\mathrm{Zn}>\mathrm{Cu}>\mathrm{Mn}>\mathrm{Cr}>\mathrm{Ni}>\mathrm{Pb}>\mathrm{As}$ \\
\hline V-SH & $\mathrm{Ca}>\mathrm{K}>\mathrm{P}>\mathrm{S}>\mathrm{Fe}>\mathrm{Mn}>\mathrm{Zn}>\mathrm{Cu}>\mathrm{Ni}>\mathrm{Cr}>\mathrm{Pb}>\mathrm{As}$ \\
\hline $\mathrm{V}-\mathrm{RP}$ & $\mathrm{Ca}>\mathrm{K}>\mathrm{P}>\mathrm{S}>\mathrm{Fe}>\mathrm{Mn}>\mathrm{Zn}>\mathrm{Cu}>\mathrm{Ni}>\mathrm{Cr}>\mathrm{Pb}>\mathrm{As}$ \\
\hline $\mathrm{V}-\mathrm{AP}$ & $\mathrm{Ca}>\mathrm{K}>\mathrm{P}>\mathrm{S}>\mathrm{Fe}>\mathrm{Cu}>\mathrm{Zn}>\mathrm{Mn}>\mathrm{Ni}>\mathrm{Pb}>\mathrm{Cr}>\mathrm{As}$ \\
\hline V-HS & $\mathrm{K}>\mathrm{Ca}>\mathrm{P}>\mathrm{S}>\mathrm{Fe}>\mathrm{Cu}>\mathrm{Zn}>\mathrm{Mn}>\mathrm{Ni}>\mathrm{Cr}>\mathrm{Pb}>\mathrm{As}$ \\
\hline V-WS & $\mathrm{K}>\mathrm{Ca}>\mathrm{P}>\mathrm{S}>\mathrm{Fe}>\mathrm{Cu}>\mathrm{Mn}>\mathrm{Zn}>\mathrm{Cr}>\mathrm{Ni}>\mathrm{Pb}>\mathrm{As}$ \\
\hline
\end{tabular}

\section{Conclusions}

The chemical composition of ash from biomass is an important feature allowing for evaluation of the behavior of elements during combustion and use of ashes.

The use of furnace waste generated by households is a positive aspect because it significantly contributes to reducing the amount of waste sent to landfills. It seems that the utilization of furnace waste is the most advantageous variant. However, it should be noted that its storage is still the most widespread form.

The aim of the conducted research was to obtain information on the main components of ashes from 35 biomass species used in combustion processes to obtain reference data for the development of utilization directions for these ashes, with particular emphasis on agricultural use. However, it should be kept in mind that these results are based on the laboratory production of ashes and may show differences in relation to those obtained in boilers. The ash content in the examined biomass ranged from 0.37 to $10.44 \%$. The chemical composition of ashes was dominated by the macroelements $\mathrm{Ca}, \mathrm{K}, \mathrm{P}$ and $\mathrm{S}$, which suggests possibility for their agricultural use. At the same time, the low content of toxic elements, such as $\mathrm{As}$ and $\mathrm{Pb}$, should not be a limiting feature in their use, with the exception of wood biomass. In addition, ashes obtained from biomass combustion were enriched with microelements such as $\mathrm{Zn}, \mathrm{Cu}$ and $\mathrm{Mn}$, which further increases their possibilities for use as fertilizer. 
The chemical composition of ashes obtained from biomass combustion was very diverse. This is due to many different factors. Generally, these factor relate to the raw material itself: the type of biomass, plant species or plant parts, growth processes and conditions, plant age, fertilization and applied dose of plant protection products, harvest time and techniques, transport and storage conditions, processing methods, as well as the process of combustion itself: fuel preparation, combustion technology, and combustion conditions plus other technical conditions. These factors can enrich or reduce the content of elements in biomass ash. Hence, due to the high diversity of ash quality, depending on the type of biomass being burned, a detailed analysis of the chemical composition of ash is required before indicating the direction of its management, especially the use as fertilizer.

The statistical analysis of the obtained research results has indicated that the potential use of ash from each type of biomass, in terms of its chemical composition, should be considered individually, not by the division into groups depending on the origin of the biomass. The adopted division was not reflected in the dependence of the analyzed elements contents in the designated groups.

Due to the variety of fuel sources from biomass with different ash properties, finding one suitable method for managing all ashes is unlikely. However, identifying the characteristics of the ash will provide valuable information on probable methods of its processing.

It should also be kept in mind that the use of biomass ash as fertilizer requires further and detailed research with long-term monitoring of the impact on soils.

Author Contributions: Conceptualization, G.Z. and J.S.-B.; Methodology, G.Z. and J.S.-B.; Validation, J.S.-B.; Formal Analysis, M.S.; Investigation, W.G.; Resources, G.Z. and W.G.; Writing-original draft preparation, J.S.-B. and G.Z.; Writing-review and editing, G.Z.; Supervision, J.S.-B.

Funding: The publication was funded by appropriations of the Faculty of Production Engineering University of Life Sciences in Lublin within the framework of grants to maintain the research potential.

Conflicts of Interest: The authors declare no conflicts of interest.

\section{References}

1. Stolarski, M.J.; Krzyżaniak, M.; Warmiński, K.; Tworkowski, J.; Szczukowski, S. Willow biomass energy generation efficiency and greenhouse gas reduction potential. Pol. J. Environ. Stud. 2015, 24, 2627-2640. [CrossRef]

2. Burg, P.; Ludín, D.; Rutkowski, K.; Krakowiak-Bal, A.; Trávníček, P.; Zemánek, P.; Turan, J.; Višacki, V. Calorific evaluation and energy potential of grape pomace. Int. Agrophys. 2016, 30, 261-265. [CrossRef]

3. Viktarovich, N.; Czechowska-Kosacka, A. Production from Biomass in a Trigeneration System. Rocz. Ochr. Sr. 2016, 18, 1007-1017.

4. Mirowski, T. Utilization of biomass for energy purpose versus reduction of emission of air pollutants from municipal and households sector. Rocz. Ochr. Sr. 2016, 18, 466-477.

5. Dołżyńska, M.; Obidziński, S. Effect of used cooking oil additive on sewage sludge combustion. Przem. Chem. 2017, 96, 1848-1851. [CrossRef]

6. Maj, G. Emission Factors and energy properties of agro and forest biomass in aspect of sustainability of energy sector. Energies 2018, 11, 1516. [CrossRef]

7. Szyszlak-Bargłowicz, J.; Zając, G.; Kuranc, A.; Słowik, T.; Dudziak, A.; Stoma, M.; Wasilewski, J. Chemical properties of selected agri-food industry waste products in the aspect of their use for energetics purposes. Przem. Chem. 2018, 97, 779-783. [CrossRef]

8. Chocyk, D.; Gładyszewska, B.; Ciupak, A.; Oniszczuk, T.; Mościcki, L.; Rejak, A. Influence of water addition on mechanical properties of thermoplastic starch foils. Int. Agrophys. 2015, 29, 267-273. [CrossRef]

9. Oniszczuk, T.; Pilawka, R. Effect of cellulose fibers on thermal strength of thermoplastic starch. Przemyst Chemiczny 2013, 92, 265-269.

10. Sornek, K.; Filipowicz, M.; Rzepka, K. Study of clean combustion of wood in a stove-fireplace with accumulation. J. Energy Inst. 2017, 90, 613-623. [CrossRef]

11. Hawrot-Paw, M.; Koniuszy, A.; Mikiciuk, M.; Izwikow, M.; Stawicki, T.; Sędłak, P. Analysis of ecotoxic influence of waste from the biomass gasification process. Environ. Sci. Pollut. Res. Int. 2017, 24, 15022-15030. [CrossRef] [PubMed] 
12. Antonkiewicz, J. Use incineration ash for binding heavy metals in soils. Environ. Protec. Nat. Resour. 2009, 41, 398-405.

13. Kajda-Szcześniak, M. Characteristics of ashes from fireplace. Arch. Waste Manag. Environ. Protect. 2014, 16, 73-78.

14. Ciesielczuk, T.; Kusza, G.; Nems, A. Fertilization with biomass ashes as a source of trace elements for soils. Environ. Protect. Nat. Res. 2011, 49, 219-227.

15. Vassilev, S.V.; Baxter, D.; Andersen, L.K.; Vassileva, C.G. An overview of the composition and application of biomass ash. Part 1. Phase-mineral and chemical composition and classification. Fuel 2013, 105, 40-76. [CrossRef]

16. Vassilev, S.V.; Baxter, D.; Andersen, L.K.; Vassileva, C.G. An overview of the composition and application of biomass ash.: Part 2. Potential utilisation, technological and ecological advantages and challenges. Fuel 2013, 105, 19-39. [CrossRef]

17. Vassilev, S.V.; Vassileva, C.G.; Baxter, D. Trace element concentrations and associations in some biomass ashes. Fuel 2014, 129, 292-313. [CrossRef]

18. Schiemenz, K.; Eichler-Löbermann, B. Biomass ashes and their phosphorus fertilizing effect on different crops. Nutr. Cycl. Agroecosyst. 2010, 87, 471-482. [CrossRef]

19. Meller, E.; Bilenda, E. Effects of biomass ash on the physicochemical properties of light soil. Energy Policy J. 2012, 15, 287-292.

20. Eriksson, J.-E.; Khazraie, T.; Hupa, L. Different Methods for the Characterization of Ash Compositions in Co-Firing Boilers. In Energy Technology 2018; The Minerals, Metals \& Materials Series; Springer: Cham, Switzerland, 2018; pp. 253-263.

21. Demirbas, A. Heavy metal contents of fly ashes from selected biomass samples. Energy Sources 2005, 27, 1269-1276. [CrossRef]

22. Vassilev, S.V.; Baxter, D.; Andersen, L.K.; Vassileva, C.G. An overview of the chemical composition of biomass. Fuel 2010, 89, 913-933. [CrossRef]

23. Reumerman, P.; Van den Berg, D. Reduction of Fouling, Slagging and Corrosion Characteristics of Miscanthus. (The BIOMIS Project) Report. Available online: http://cordis.europa.eu/project/rcn/48287_en.html (accessed on 24 June 2018).

24. Száková, J.; Ochecová, P.; Hanzlíček, T.; Perná, I.; Tlustoš, P. Variability of total and mobile element contents in ash derived from biomass combustion. Chem. Pap. 2013, 67, 1376-1385. [CrossRef]

25. Demirbas, A. Combustion of biomass. Energy Sources 2007, 29, 549-561. [CrossRef]

26. Demirbas, A. trace metal concentrations in ashes from various types of biomass species. Energy Sources 2003, 25, 743-751. [CrossRef]

27. Thy, P.; Yu, C.; Jenkins, B.M.; Lesher, C.E. Inorganic composition and environmental impact of biomass feedstock. Energy Fuels 2013, 27, 3969-3987. [CrossRef]

28. Umamaheswaran, K.; Batra, V.S. Physico-chemical characterisation of Indian biomass ashes. Fuel 2008, 87, 628-638. [CrossRef]

29. Wang, G.; Shen, L.; Sheng, C. Characterization of biomass ashes from power plants firing agricultural residues. Energy Fuels 2012, 26, 102-111. [CrossRef]

30. Vamvuka, D.; Kakaras, E. Ash properties and environmental impact of various biomass and coal fuels and their blends. Fuel Process. Technol. 2011, 92, 570-581. [CrossRef]

31. Vassilev, S.V.; Baxter, D.; Andersen, L.K.; Vassileva, C.G.; Morgan, T.J. An overview of the organic and inorganic phase composition of biomass. Fuel 2012, 94, 1-33. [CrossRef]

32. Tsuchiya, Y.; Shimogaki, H.; Abe, H.; Kagawa, A. Inorganic elements in typical Japanese trees for woody biomass fuel. J. Wood. Sci. 2010, 56, 53-63. [CrossRef]

33. Monti, A.; Di Virgilio, N.; Venturi, G. Mineral composition and ash content of six major energy crops. Biomass Bioenergy 2008, 32, 216-223. [CrossRef]

(C) 2018 by the authors. Licensee MDPI, Basel, Switzerland. This article is an open access article distributed under the terms and conditions of the Creative Commons Attribution (CC BY) license (http:/ / creativecommons.org/licenses/by/4.0/). 